\title{
Psychotherapy under Capitalism: The Production, Circulation and Management of Value and Subjectivity
}

IAN PARKER, University of Leicester, UK and University of the Witwatersrand, South Africa

ABSTRACT This paper is about the place of psychotherapy under capitalism, addressed using elements of the critique of political economy undertaken by Marx. Marxist critique of capitalist political economy is also, it is argued, necessarily feminist. I include analyses of "feminisation" of work in order to grasp how value is produced, circulated and managed by psychotherapy, how subjectivity is targeted. Three aspects of psychotherapy are discussed to illustrate the value of a Marxist feminist approach to this particular practice of the self: the question of payment for the labour of a psychotherapist (and the labour of the client), the question of public health provision (focusing here on the UK National Health Service), and the continuing debates about the role of the State (and the regulation of public and private provision of psychotherapy).

Keywords: Political economy; Marxism; feminism; value; subjectivity

The question of "social context" in psychotherapy is central to attempts to embed our practice in relation to broader, and more obviously, "political" interventions, and this social context is inescapable when we reflect on the place of our work internationally. A standard response to this question is to focus on the particular cultural contents - beliefs, attitudes, ideological systems - that have a bearing on the way that the therapist and client engage with each other. Much useful work has been done on the intersection between politics and psychotherapy which explores the different ways in which the particular content of political ideologies influences different therapeutic models (e.g., Totton, 2000, 2006), and recent attention to the "relational" aspects of therapy have emphasised the way the content of the therapy is informed by the political stance, whether acknowledged or not, of the therapist (and client) (Loewenthal and Samuels, 2014).

Another way of approaching the question of social context, however, is to focus on the formal properties of therapy as a practice of the self, what Foucault (1984/1986) called the "care of the self" in contemporary society, and to locate this therapeutic care of the self in the political-economic formation that is now globally-dominant, capitalism. The analysis of "political economy" was undertaken as capitalism was developing in the nineteenth century, and was designed to be not only an analysis of this particular mode of production but also a recommendation for it. This liberal political economy was predicated on the idea that individuals enter into relationships with each other on the basis of a free contract, and that the profits that result from that contract can then be invested in order to bring about economic growth (Smith, 1776). A number of ideological presuppositions were brought into play for this vision of the 'free market' to work, which included the idea that the role of the State should be minimal, and that the family was the natural unit for the reproduction of labour and exemplar of care for others (Poster, 1978).

Although it is possible to argue that there were already quasi-therapeutic elements to social relationships at this point, and perhaps even before capitalism - and this argument tends to underpin the notion that there are social practices of care for others and care of the self in pre-capitalist cultures that radical therapy could today learn from - the management of distress was quite different from the way it is understood today. 
Psychotherapy (a term I use in this paper in its broadest sense to include counselling and psychoanalysis) developed as a professionalised practice devoted to subjectivity that works on a series of assumptions about work and family relationships and, whether the psychotherapist likes it not, regulative mechanisms of which the State under capitalism is the model (Donzelot, 1979).

Marx's (1867) response was to produce an analysis of "Capital" which was a critique of political economy, a critique that entailed not only an examination of the economy as such but also of the role of the State in maintaining this economy and, particularly in the work of his co-worker Engels (1884/1972), the role of the family as necessarily intertwined with the institution of private property and the State. A Marxist critique of political economy today must include the classical elements of Marx's (and Engels's) analysis of the production and circulation of value, it must include an analysis of the changing relation between the State and so-called "civil society", and it must include an analysis of the production and reproduction of gender and the way that women are specifically oppressed under capitalism (Arruzza, 2013). This last inclusion of a feminist critique alongside Marxist critique will also enable us to grasp the place of psychotherapy in capitalism as an apparatus that not only participates in the production of value but also how psychotherapeutic practice has become more important to the production, circulation and management, in both the State and civil society, of subjectivity. Let us take those three aspects briefly in turn.

\section{INTERSECTIONS OF VALUE, THE STATE, AND FEMINISATION}

For Marx (1867), value does not lie hidden within commodities - things we buy and sell but is a function of the relationship between them, and value itself is a function of a quite specific set of social relationships, the "relations of production". Under capitalism the relations of production are such that workers must sell their labour power, work for a particular period of time for the payment of that power - payment which enables them to feed and house themselves and their families, and thereby ensure the reproduction of the labour force - and then work an additional period of time which gives rise to the "surplus value" that is realised by their employer as their own profit. Marx distinguishes between the "exchange value" of commodities - a value that arises from the equivalence between them on the market-place - and their "use value", but this "use value" - which seems to be the real underlying and meaningful value of a product - is produced, not given, and cannot be taken for granted as something hidden inside the commodity (Žižek, 1989).

There are a number of consequences of this production and concealment of value for subjectivity. One is the "alienation" of the worker from the products of their labour, for they have no control over the creative process, and "surplus value" is effectively stolen from them in order that their employer will be able to realise it as profit (when they sell the products as commodities). This alienation introduces a separation of the worker from their own creativity, divides the worker from their fellows as they compete for work, and makes the worker fearful of their own body, which they rely on as a kind of machine to do the work (Kovel, 2007). Another consequence, which compounds the first, is that the worker is also turned into a commodity as a thing that is "fetishised" under capitalism, assumed to be the location of value, something to be bought and sold. Most forms of distress that a psychotherapist encounters in their clinic are expressions of these basic processes of alienation and fetishisation (Kovel, 1981). 
For Marx, capitalism is a system of social processes that appear in the consciousness of the subjects of this system as if they are separate things (Bensaïd, 2002). One of the most powerful elements of capitalism as a system of social processes is the State, for it is the State which guarantees the accumulation of capital and protects private property, most crucially the property of those who live off the surplus value of workers they employ. The State becomes separated, split off from "civil society" as the everyday sets of relationships which comprise the "free market", and this State pretends to be a neutral arbiter between the classes while actually it "protects the imaginary universality of particular interests" (Marx, 1843, 107).

This State has always, as Engels (1884/1972) noted, also protected the particular interest of men and the institution of the family has historically been a place where women's labour in the reproduction of the workforce has been rendered invisible. As early liberal "free market" capitalism in the nineteenth century mutated into welfare capitalism in the twentieth and then into contemporary "neoliberal" capitalism, women's labour became more important, and the stereotypical qualities of women's work in the service sector - a kind of labour that attends to relationships with customers - have led to what has been termed the "feminisation" of work (Hochschild, 1983).

In order to grasp the nature of this feminised practice, we need to step back and trace political-economic changes in the relationship between labour and capital which traditionally produced value in the early years of capitalism and the emergence of contemporary forms of domestic labour in the separate realm of the family (Donzelot, 1979). Domestic labour does not, according to some classical Marxist arguments, give rise to surplus value because its products are not exchanged in the market place in order that the immediate beneficiaries might realise a profit (Arruzza, 2013). In realising a profit, the appearance of some kind of exchange value of the product would thereby also make evident to those involved that there was some use value, and this would then also make visible the exploitation of the labour power of women. This a matter of some debate, and the question is at the centre of contemporary debates within feminism over the political value of campaigning for "wages for housework" (Federici, 2012). Early industrialisation did actually in many cases draw upon the labour of women who were effectively what would today be called "home-workers" (Marcus, 1974). This is not to say that domestic labour was "unproductive" because it still assured the "reproduction" of labour power. The family was a site of labour crucial to the formation and maintenance of the workforce, and this labour was then supplemented to an extent by the welfare state (Anderson, 2000).

A political economy of psychotherapy - that is, an approach to psychotherapy which grasps it as a political and economic factor in the process of production and reproduction in capitalist society - raises a number of questions about everyday practice. Let us turn to three aspects of life under contemporary capitalism that have consequences for the way we think of our own work as psychotherapists.

\section{PAYMENT}

The first aspect concerns the role of money in therapy, and draws attention to some intriguing dividing lines between psychologically-oriented psychotherapists and those who are psychoanalytic. A friend who works as a psychologist providing educational support and psychotherapy advised me that I should make sure that my clients pay me before the session rather than let them pay afterwards. I was puzzled by this, and it led me to think 
about what the underlying differences might be between psychology and psychoanalysis that they would relate to money in such different ways.

Under capitalism there are some kinds of commodities that are usually paid for in advance, and these range from food from shops (usually reinforced by the rule that you should not eat the product before you have passed the checkout) to transport (where you will be fined for travelling without a ticket). Large items like cars and houses are governed by contract in which the deposit serves as advance payment, with the remainder viewed as a loan for money already paid (which is why it attracts interest). These commodities are by and large for biological needs (food, clothing and housing, for example).

Transport and other services that have indeterminate cost are usually paid for after the event. A meal at a restaurant (as opposed to cheaper self-service cafeteria food) is paid for afterwards, for example, as would an individually-tailored suit. These commodities are as a general rule goods that are not immediately and directly necessary, but fall within the realm of what is sometimes referred to by the exchequer as "luxury items". In class terms, the first group of commodities paid for in advance are those that nurture and sustain labour power as itself a commodity, while the second group of commodities operate in the domain of the petit bourgeoisie, or those who are incited to aspire to escape the condition of being working class.

In the service sector (broadly conceived) there are a range of practices. Prostitutes usually ask for payment in advance, and there is some discussion about the relation between counselling and prostitution. A reflection on this connection by a "coach" and counsellor in private practice put it like this: "The cash in my hand is a reminder that I have just delivered a professional service, but a service that sets a time limit to the unconditional positive regard it offers" (Ryan, 2012).

In Capital, Marx (1867) makes the following comment:

In every country in which the capitalist mode of production reigns, it is the custom not to pay for labour power before it has been exercised for the period fixed by the contract, as for example, the end of each week.

It could be argued that a strict time limit for sessions in most forms of psychotherapy and psychoanalysis is not only "obsessional" as such (adapted to the calculation of time and effort) on the part of the provider, but encourages obsessional behaviour on the part of the client (Parker, 2011). The calculation of ranges of payment on a "sliding scale" suited to the ability to pay by the client would not then break from this logic but reinforce it. The assumption here is that the "product" must be the same, but that generosity in line with some kind of utilitarian assessment of costs and benefits for each and every member of society would enable the therapist to determine how access to resources could be levelled out.

Some kinds of psychoanalysis break from this logic by varying the length of the session but charging the same amount - among other things, the message is that you do not get exactly what you pay for - and some practitioners will even increase the number of times that the client comes to see them without changing the overall fee (which really drives this message home). And to take payment after the session sends a double message. On the one hand it frames the analysis as the preserve of those who have escaped the domain of working class "need" economy and are paying for a "luxury" item. On the other hand it does make it clear that this is something that concerns need at the level of what we 
could call "second nature", of the psychic economy that deals with things that are not only immediately productive and measurable.

\section{PUBLIC PROVISION}

The second aspect concerns the role of a state-funded health service, in Britain this is the National Health Service (NHS) instituted by the Labour Party in 1945 after it formed a government following the Second World War. On the one hand, this massive apparatus of health provision was a victory for the working class, and the recent endeavours of the Conservative government (in coalition with the Liberal Democrats) to dismantle and privatise it have met opposition from the Trades Unions. On the other hand, the NHS has been a crucial mechanism for ensuring that what Marx referred to as the "reserve army of labour" which serves as a population of fluctuating size depending on the needs of employers is kept healthy enough to play its function. Marx (1867) notes in Capital, for example, that those capitalist states that refused to put resources into the health of the population paid dearly when their populations were not then ready for work, or for war when the state wanted to defend itself against other states.

Even so, it has been noted that "Almost by definition, the NHS was originally dedicated to supporting people who were who were outside the of the labour market - new mothers, children, the sick, the elderly and the dying" (Davies 2011, 65), and so the practice until recently was that doctors would issue "sick notes" which patients would use to notify employers that they were not able to work. Now such notes are being replaced with socalled "fit notes" which are designed to inform the employer what kind of work the patient is still able to perform (National Health Service, 2012).

The shift to neoliberal capitalism is now not merely a return to the savage unregulated competition of the nineteenth century - and even then, as I pointed out earlier, the state was always already involved in ameliorating the worst exploitation all the better to ensure that the conditions for exploitation were maintained - but this shift entails taking into account mental and emotional processes, precisely taking into account the domain which psychotherapy has made its own. This is the "immaterial" or "cognitive" aspect of labour described by Hardt and Negri (2004), and we are taken way beyond the remit of classical political economy which preferred "the metaphor of "human capital", which treats the mind as analogous to physical fixed capital, such as machinery" (Davies, 2011, 75).

This then means that "adaptation" to capitalism requires psychotherapists not merely to ameliorate the worst excesses of the system, but to ensure that this adaptation is geared to inciting and channelling the critical reflexive energy of citizens so that the very critique that they make of the economy serves to fine-tune it (Boltanski and Chiapello, 2007). The "new spirit of capitalism", as Boltanski and Chiapello (2007) call it, then "regulates the political economy of unhappiness, aiming to ensure that individuals find partial fulfilment in work and consumption" (Davies, 2011, 71). The neoliberal state thus governs the health of its citizens in such a way as to ensure that they are ready to work to some degree - this is what the move to "fit notes" accomplishes - and to focus on capabilities which are not merely "physical" but will include mental and emotional aspects. Psychotherapy thus become crucial to the state health apparatus as a practice devoted to the balance of dissatisfaction and yearning requisite for consumption and production. Davies $(2011,67)$ in a very useful discussion of the current "political economy of unhappiness" argues that: 
Depression is the iconic illness in this respect. Indeed, we might say that if "immaterial" labour is now the hegemonic form of production, depression is the hegemonic form of incapacity ... Depression is just sheer incapacity, a distinctly neoliberal form of psychological deficiency, representing the flipside of an ethos that implores individuals to act, enjoy, perform, create, achieve and maximise.

If this account is right, then the suspicion of some Marxists that state health serves to maintain the workforce as one geared to the needs of capitalism would seem more plausible, and, furthermore, suspicion of psychotherapists working in the National Health Service would seem equally if not more so. However, this still provides support for people who would not be able to afford to pay for health care. There is a dialectical relationship between the needs of the state and the prefiguration of the systemic provision that would be provided in an economy that was not geared for profit. There is a tradition of very low cost and even free provision in psychoanalysis that reflected the reformist and even sometimes revolutionary sympathies of psychoanalysts in continental Europe before the rise of fascism (Danto, 2005). Marx (1867) provided a critique of the dominant forms of political economy that was oriented to justifying capitalism, but with the purpose of establishing the basis for an alternative political economic system based on human needs which the NHS anticipates.

\section{REGULATION}

Let us turn to the third aspect of psychotherapy under capitalism, which is where we look at the role of the State in regulating psychotherapeutic practice (Parker and Revelli, 2008). This is not to overplay the importance of psychotherapy in capitalist society, and at times of crisis - recurrent crises that are a feature of the laws of motion of this kind of economy - it will be viewed by some sectors of the bourgeoisie and the state apparatus as dispensable. There is an intense ideological tension, for example, between those in the State keen to use psychotherapy itself as a regulative apparatus in which people are encouraged to account for the political problems they face at times of increasing unemployment as their own personal responsibility, and those who would dismiss this appeal to internal emotional upset on the basis that it reduces the "resilience" of people to cope and then fight their own way out of unemployment (Fryer and Stambe, 2014).

This ideological tension is reflected in different policy initiatives by the UK government, for example. Under the previous Labour administration there was support for the "Increasing Access to Psychological Therapies" initiative which promised to bring people off incapacity benefit for at least six months, which its proponents argued would make good economic sense and cover the cost of training if sufficient investment was made (Layard, 2006), and in the current Conservative and Liberal Democrat Coalition who view the programme as a luxury, as keeping clients dependent on the state rather than releasing them into what the Prime Minister David Cameron refers to as the "big society" where they will have to choose to work or starve (Blond, 2010).

Let us map out, rather schematically, three domains where psychotherapy operates, and then we will be in a better position to understand how psychotherapy intersects with the capitalist State, and anticipate which practitioners are likely to be sympathetic to attempts by the State to regulate psychotherapy. There are, first, individual self-employed 
psychotherapists responsible for contracting themselves to labour for one other person (or in some cases for a group that they must assemble as paying customers, with this elision of "employer" and "customer" a feature of privatised service-sector labour). We can subcategorize these individuals into those who have made psychotherapy a career from the beginning, those who have re-skilled as psychotherapists, and those who have moved out from the sphere of domestic labour to train and enter the market-place. Then, second, there are those in employment (with the job description of psychotherapist, counsellor, counselling psychologist or psychoanalyst). These we can sub-categorize into those working for a commercial enterprise, those working for a charity or non-governmental organisation, those working for public welfare services, and those working in an educational institution. A third group will be those who take a more explicitly administrative function, and here we can include sub-categories of consultants usually working self-employed for an organisation, those employed by psychotherapy training organisations, and those on a committee, including in a registration or regulatory body (who are paid, or can work unpaid if they have other sources of income).

It is possible to identify which of these groups will be most susceptible to arguments for regulation, either because they are competing with other psychotherapists for work or because they are already working in or alongside the state apparatus, or because of both of these things at the same time. The other kind of data we need concerns the functioning of the different institutional apparatuses. This would focus, for example, on the way that the disciplinary process in registration bodies has economic underpinning. To take just one case we have access to figures for, the Health Professions Council finance report includes "the fitness to practise case management system" under what it calls "[i]ntangible asset additions" (Health Professions Council, 2010, 29).

Data on the functioning of the institutional apparatuses charged by the state with regulating psychotherapy should also crucially include detailed qualitative analysis of it, and a rich source of ethnographic material is now available (Haney, 2012). The internal workings of the committees are not completely visible to the public, but what is public confirms Marx's prescient comments on the nature of bureaucracy under capitalism. He says:

The bureaucracy holds the state, the spiritual essence of society, in thrall, as its private property. The universal spirit of bureaucracy is secrecy, it is mystery preserved within itself by means of the hierarchical structure and appearing to the outside world as a self-contained corporation. (Marx, 1843, 108)

This is not merely a complaint about bureaucracy, but an attempt to embed the bureaucratic aspect of the state in the accumulation and circulation of capital, which it is the function of the state to guarantee under capitalism (Mandel, 1992). Just as capitalism requires the enclosure of natural resources so that they may then be bought and sold, so it requires the enclosure of labour power in the person of the labourer so that they may then enter into a contract with others to sell it for a fixed period of time. This enables us to grasp something of the "social context" in which psychotherapists seem to be willing to accede to State regulation to the point of mutilating their own practice (Reeves and Mollon, 2009).

\section{CONCLUSIONS}


With the reconfiguration of domestic labour as a commodity for sale on the open market and as resource for the development of the welfare state, capitalism also requires the enclosure of emotional labour, and from this come attempts to delimit and define what the commercial and institutional benefits of "emotional literacy" are, for example (Burman, 2001). Marx comments on the way that this process operates as part of the logic of the capitalist State which outruns intention and feeling, but which also instates a demand for obedience which psychotherapists would recognise as being charged with affect. Marx says that the bureaucracy makes "the real mindlessness of the state into a categorical imperative" (p. 107); we might recall that Freud was fond of claiming that the categorical imperative was effectively superegoic. Psychotherapy as a form of emotional labour then produces value that is realised as surplus value invested in, among other places, bureaucratic administration. Psychotherapeutic practice is thus part of the "spiritual essence" of contemporary society, and so becomes a component part of the essence of the state as its "private property". Intrude upon the activities of the regulatory bodies who have charged themselves with protecting psychotherapy and you threaten their private property, that which they have come to possess as if they held in their hands the essence of the state.

The account I offer in this paper is, of course, very rudimentary, and a more detailed analysis is needed of the composition of different places where there is psychotherapeutic labour and of the value that is produced in them and then circulated for profit. To take this preliminary account further we would need to examine in more detail the landscape of this labour process and the forms of value produced by it. This paper merely sets out pointers to the research that still needs to be carried out to deepen a Marxist analysis.

\section{REFERENCES}

Anderson, B. (2000) Doing the Dirty Work?: The Global Politics of Domestic Labour. London: Zed Books.

Arruzza, C. (2013) Dangerous Liaisons: The Marriages and Divorces of Marxism and Feminism. London: Resistance Books.

Bensaïd, D. (2002) Marx for our Times: Adventures and Misadventures of a Critique. London: Verso.

Blond, P. (2010) Red Tory: How Left and Right Have Broken Britain and How We Can Fix It. London: Faber.

Boltanski, L. and Chiapello, E. (2006) The New Spirit of Capitalism. London: Verso.

Burman, E. (2001) 'Emotions in the classroom: and the institutional politics of knowledge', Psychoanalytic Studies, 3, pp. 313-324.

Danto, E. A. (2005) Freud's Free Clinics: Psychoanalysis and Social Justice, 1918-1938. New York: Columbia University Press.

Davies, W. (2011) 'The political economy of unhappiness', New Left Review, 71, pp. 65-80.

Donzelot, J. (1979) The Policing of Families. London: Hutchinson.

Engels, F. (1884/1972) The Origin of the Family, Private Property and the State. New York: Pathfinder Press.

Federici, S. (2012) Revolution at Point Zero: Housework, Reproduction, and Feminist Struggle. Oakland, CA: PM Press.

Foucault, M. (1984/1986) The Care of the Self: The History of Sexuality Vol III, Harmondsworth: Penguin. 
Fryer, D. and Stambe, R. (2014) 'Neoliberal austerity and unemployment', The Psychologist, 27(4), pp. 244-248.

Haney, J. (2012) Regulation in Action: The Health Professions Council Fitness to Practise Hearing of Dr Malcolm Cross - Analysis, History, and Comment. London: Karnac.

Hardt, M. and Negri, T. (2004) Multitude: War and Democracy in the Age of Empire. New York: The Penguin Press.

Health Professions Council (2010) Annual Report and Accounts 2009-10. London: The Stationery Office.

Hochschild, A. R. (1983) The Managed Heart: Commercialisation of Human Feeling. Berkeley, CA: University of California Press.

Kovel, J. (1981) The Age of Desire: Case Histories of a Radical Psychoanalyst. New York: Pantheon.

Kovel, J. (2007) The Enemy of Nature: The End of Capitalism or the End of the World? $\left(2^{\text {nd }}\right.$ Revised edn). London: Zed Books.

Layard, R. (2006) The Depression Report: A New Deal for Depression and Anxiety Disorders. London: LSE Centre for Economic Performance, available at http://cep.Ise.ac.uk/research/mentalhealth/default.asp (accessed 8 April 2014).

Loewenthal, D. and Samuels, A. (eds) (2014) Relational Psychotherapy, Psychoanalysis and Counselling: Appraisals and reappraisals. Abingdon/New York: Routledge.

Mandel, E. (1992) Power and Money: A Marxist Theory of Bureaucracy. London: Verso.

Marcus, S. (1974) Engels, Manchester, and the Working Class. New York: W. W. Norton.

Marx, K. (1843) 'Critique of Hegel's doctrine of the state', in Marx, K. (1975) Karl Marx: Early Writings (pp. 57-198). Harmondsworth: Pelican.

Marx, K. (1867) Capital: A Critique of Political Economy Volume I.

https://www.marxists.org/archive/marx/works/1867-c1/ (accessed 18 September 2013).

National Health Service (2012) 'What are fit notes?', http://www.nhs.uk/chq/Pages/2584.aspx (accessed 8 April 2014).

Parker, I. (2011) Lacanian Psychoanalysis: Revolutions in Subjectivity. Abingdon/New York: Routledge.

Parker, I. and Revelli, S. (eds) (2008) Psychoanalytic Practice and State Regulation. London: Karnac.

Poster, M. (1978) Critical Theory of the Family. London: Pluto.

Reeves, R. and Mollon, P. (2009) 'The State Regulation of Psychotherapy: From SelfRegulation to Self-Mutilation?, Attachment: New Directions in Psychotherapy and Relational Psychoanalysis, 3, pp.1-19.

Ryan, K. (2012) 'Cash in the hand', Therapy Today, 23, (7), http://www.therapytoday.net/article/show/3302/ (accessed 13 August 2014).

Smith, A. (1776) An Inquiry into the Nature and Causes of the Wealth of Nations, http://www.econlib.org/library/Smith/smWN.html (accessed 13 August 2014).

Totton, N. (2000) Psychotherapy and Politics. London and Thousand Oaks, CA: Sage.

Totton, N. (ed.) (2006) The Politics of Psychotherapy: New Perspectives. Buckingham: Open University Press.

Žižek, S. (1989) The Sublime Object of Ideology. London: Verso. 